\title{
Sorbic Acid as an Alkylating Agent
}

\author{
M. Teresa Pérez-Prior · José A. Manso • \\ M. del Pilar García-Santos · Emilio Calle · Julio Casado
}

Received: 20 July 2007 / Accepted: 6 October 2007 / Published online: 8 February 2008

(C) Springer Science+Business Media, LLC 2008

\begin{abstract}
A kinetic study of the alkylating potential of the sorbic acid $+\mathrm{NaOH}$ and sorbic acid $+\mathrm{KOH}$ systems was performed in 7:3 (volume/volume) water + dioxane solvent mixtures. The following conclusions were drawn. First, the sorbic acid + sorbate system shows alkylating activity on the nucleophile 4-( $p$-nitrobenzyl)pyridine (NBP), which is used as a trap for alkylating agents having nucleophilic characteristics similar to DNA bases. Second, the maximum alkylating capacity is observed in the $\mathrm{pH}=5.0$ to 6.5 range. Third, the alkylation reactions comply with the rate equation $r=k_{\mathrm{alk}}\left[\mathrm{H}^{+}\right][\mathrm{S}][\mathrm{NBP}] /\left(K_{a}+\left[\mathrm{H}^{+}\right]\right)$, with $K_{a}$ being the dissociation constant of sorbic acid. Fourth, an enthalpy-entropy $\left(\Delta H^{\#} / \Delta S^{\#}\right)$ compensation effect for activation quantities is observed by comparing NBP alkylation reactions due to sorbic acid $+\mathrm{NaOH}$, sorbic acid $+\mathrm{KOH}$, as well as potassium sorbate + $\mathrm{HCl}$ mixtures. Fifth, the results may help to establish suitable expiration times for products preserved with sorbic acid.
\end{abstract}

Keywords Sorbic acid · Alkylating potential $\cdot$ Food preservatives

\section{Introduction}

Sorbic acid and its salts are used as preservatives in a large number of foods, feeds, pharmaceuticals, cosmetics and packaging material. The antimicrobial properties of sorbic acid were discovered independently in 1939 and 1940 by Müller and Gooding [1] (in Germany and the USA, respectively). After this discovery, sorbic acid and its salts were tested and used in a variety of consumer products for the inhibition of growth of yeast and molds, and for control of certain bacteria [2].

Sorbates have been reported to be more efficient and less toxic than benzoate [1] and are classified as 'Generally Recognized as Safe' (GRAS) additives by the FDA [3]. In the European Union, the use of sorbic acid (E200) and its potassium (E202) and calcium (E203) salts

M.T. Pérez-Prior · J.A. Manso · M. del Pilar García-Santos · E. Calle · J. Casado ( $\varangle)$

Departamento de Química Física, Universidad de Salamanca, Plaza de la Merced, 37008 Salamanca,

Spain

e-mail: jucali@usal.es 

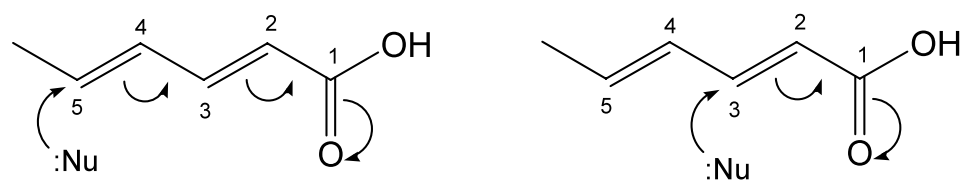

Scheme 1 Nucleophilic attack to the molecule of sorbic acid

is authorized to lengthen the shelf life of many foods (including margarine, fruit preserves and desserts, wines and other drinks, moist cheeses, etc.) [4].

Sorbic acid and potassium sorbate are less genotoxic than sodium sorbate [5], the two forms that are considered as GRAS. Significant data [6] indicate there is a weak genotoxic potential for stored sodium sorbate solutions. Accordingly, sodium sorbate is no longer in use as a food preservative and is not commercially available [7].

Sorbic acid has a conjugated system of double bonds that renders it susceptible to nucleophilic attack by species such as thiols [8,9], amines [10] and nitrites [11, 12], sometimes producing mutagenic products [4]. Strong nucleophiles, such as amines and thiols, yield 1,4-addition products without the need for an initial protonation of the sorbate, the addition of $\mathrm{H}^{+}$taking place as the final stage in the mechanism [9]. The much greater extent to which the charge on the intermediate is delocalized (arising from at attack at position 5 of sorbic acid) suggests that this position should be preferred, despite the lower electron density at position 3 (see Scheme 1).

The nucleophile NBP, 4-( $p$-nitrobenzyl)pyridine, which is a trapping molecule for alkylating agents [13] with nucleophilic characteristics similar to DNA bases [14], has previously been used by us to measure the alkylating potential of lactones [15-17]. A correlation was found between their alkylating capacity and carcinogenicity [18].

Although many aspects related to the worldwide use of sorbic acid and its salts as food preservatives have long been known, there is little quantitative knowledge about their alkylating potential.

In our previous work the alkylating potential of potassium sorbate in aqueous hydrochloric acid conditions was studied [19]. In the present study, the alkylation of NBP by sorbic acid $+\mathrm{KOH}$ and sorbic acid $+\mathrm{NaOH}$ mixtures was investigated and the results are compared.

\section{Experimental}

\subsection{Materials}

NBP was from Sigma; sorbic acid, potassium hydroxide and dioxane were purchased from Panreac (Barcelona, Spain); sodium hydroxide was from Fluka, and $\mathrm{Et}_{3} \mathrm{~N}$ (99\%) was obtained from Aldrich. Water was deionized with a Milli Q-Gradient (Millipore) system.

A Shimadzu UV-2401-PC spectrophotometer with a thermoelectric six-cell holder temperature control system $\left( \pm 0.1{ }^{\circ} \mathrm{C}\right)$ was used. A Crison Micro pH $2000 \mathrm{pH}$ meter with a 5202 electrode was used for the $\mathrm{pH}$ measurements [20].

The reaction temperature was kept constant $\left( \pm 0.05^{\circ} \mathrm{C}\right)$ with a Lauda Ecoline RE120 thermostat. All kinetic runs were performed in triplicate. 


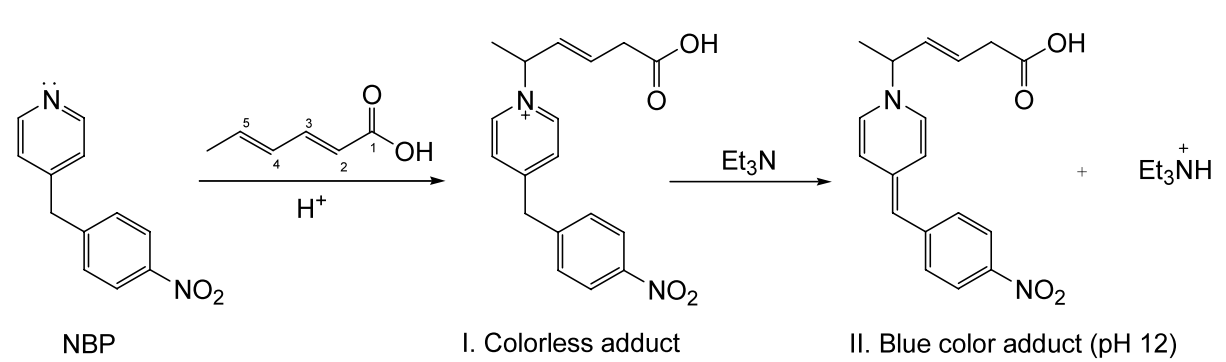

Scheme 2 Method for monitoring the NBP alkylation by sorbate

\subsection{Methods}

Alkylation reactions of sorbate $\mathrm{S}$ (expressed as the sum of the concentrations of undissociated sorbic acid $\mathrm{AH}$, plus that present as the sorbate anion $\mathrm{A}^{-}$) were carried out at constant $\mathrm{pH}$ over the range $\mathrm{pH}=5.0$ to 6.5 that is frequently found in foods [2], e.g., bread: $\mathrm{pH}=$ 5.0 to 6.0 ; chicken: $\mathrm{pH}=5.5$ to 6.4 ; cheese: $\mathrm{pH}=5.0$ to 6.1 ; beef: $\mathrm{pH}=5.3$ to 6.2 ; etc. The $\mathrm{S}+\mathrm{NaOH}$ and $\mathrm{S}+\mathrm{KOH}$ systems act as buffers, keeping the $\mathrm{pH}$ constant. In order to make NBP sufficiently soluble, the alkylation mixtures $(\mathrm{S}+\mathrm{NBP}+\mathrm{NaOH}$ or $\mathrm{KOH})$ were prepared in a 7:3 (volume/volume) water + dioxane medium.

To monitor the alkylation reactions, $2.4 \mathrm{~mL}$ aliquots of the alkylation mixture were removed at different times and added to a cuvette containing $0.6 \mathrm{~mL}$ of $99 \%$ triethylamine reagent $\left(\mathrm{Et}_{3} \mathrm{~N}\right)$ to terminate the alkylation process (Scheme 2). Then, the absorbance was measured at the wavelength of maximum absorption $(\lambda=580 \mathrm{~nm})$. Detailed reaction conditions are given in the figures and tables legends.

\section{Results and Discussions}

\subsection{Kinetics of the Alkylation Reaction}

The blue-colored sorbate + NBP adduct showed a maximum absorption at $\lambda=580 \mathrm{~nm}$. For example, Fig. 1 shows the increase in absorption caused by formation of the adduct over time, until no further change in absorbance $(A)$ was observed. Because the sorbate concentration was in large excess as compared with NBP, it may be assumed that all of the NBP was converted into the adduct (AD).

At $\mathrm{pH} \leq 5$, the alkylation reaction cannot be followed because crystals of sorbic acid begin to precipitate (the solubility of sorbic acid is $0.16 \%$ in water at $25^{\circ} \mathrm{C}$ whereas those of its potassium and sodium salts are over $138 \mathrm{~g}$ and $20 \mathrm{~g}$ per $100 \mathrm{~mL}$ water, respectively) $[1,2]$. Figure 2 represents a typical kinetic run for the alkylation of NBP by sorbic acid in the $\mathrm{S}+\mathrm{NBP}+\mathrm{KOH}$ alkylation mixture.

Because (i) the reactivity of sorbate increases with decreasing $\mathrm{pH}$, and (ii) the antimicrobial activity of the organic acids and their salts is mainly attributed to the inhibiting action of the undissociated acid molecule [2, 21, 22], in a previous work the reaction mechanism shown in Scheme 3 was proposed by us [19], where $K_{a}$ is the sorbic acid dissociation constant and $k_{\text {alk }}$ is the NBP alkylation rate constant for the undissociated acid.

Because

$$
[\mathrm{S}]=[\mathrm{AH}]+\left[\mathrm{A}^{-}\right]
$$


Fig. 1 Spectrograms showing the formation of the sorbate + NBP adduct concentration over time in 7:3 (volume/volume) water + dioxane mixtures, obtained as the variation of the absorbance from 1 to 13 days. Conditions:

$[\mathrm{S}]_{\mathrm{o}}=0.15 \mathrm{~mol} \cdot \mathrm{L}^{-1},[\mathrm{KOH}]=$ $0.1 \mathrm{~mol} \cdot \mathrm{L}^{-1}$,

$[\mathrm{NBP}]_{\mathrm{o}}=0.003 \mathrm{~mol} \cdot \mathrm{L}^{-1}, \mathrm{pH}=$ 5.78 , and $t=35.0^{\circ} \mathrm{C}$
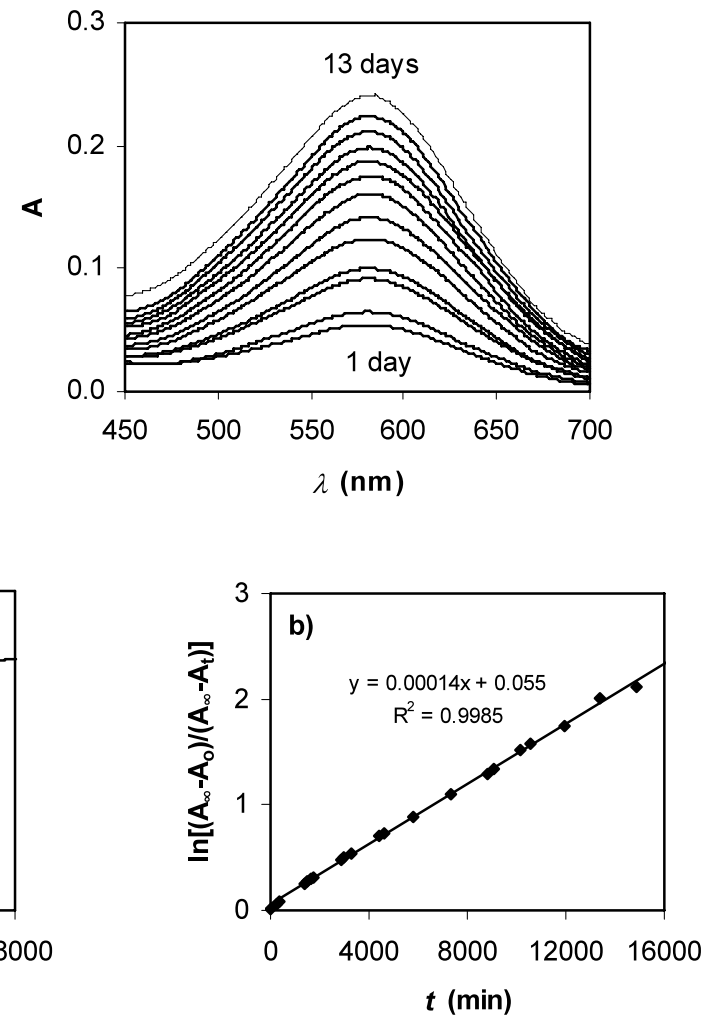

Fig. 2 (a) Formation of the sorbate + NBP adduct in 7:3 (volume/volume) water + dioxane mixtures. Variation in the absorbance $(\lambda=580 \mathrm{~nm})$ with time, with $A_{\infty}$ being the absorbance of the adduct when all the NBP has been consumed. (b) Determination of the NBP alkylation pseudo-first-order rate constant $\left(k_{1}\right.$ in Eq. 7) by sorbate in 7:3 (volume/volume) water + dioxane mixtures. Conditions: $[\mathrm{S}]_{\mathrm{o}}=0.15 \mathrm{~mol} \cdot \mathrm{L}^{-1}$, $[\mathrm{KOH}]=0.1 \mathrm{~mol} \cdot \mathrm{L}^{-1},[\mathrm{NBP}]_{\mathrm{o}}=0.003 \mathrm{~mol} \cdot \mathrm{L}^{-1}, \mathrm{pH}=5.78$, and $t=35.0^{\circ} \mathrm{C}$

Scheme 3 NBP alkylation by sorbate

$$
\begin{aligned}
& \mathrm{AH} \stackrel{K_{a}}{\rightleftarrows} \mathrm{A}^{-}+\mathrm{H}^{+} \\
& \mathrm{AH}+\mathrm{NBP} \stackrel{k_{\text {alk }}}{\longrightarrow} \mathrm{AD}
\end{aligned}
$$

and $K_{a}=\left(\left[\mathrm{A}^{-}\right]\left[\mathrm{H}^{+}\right]\right) /[\mathrm{AH}]$, Eq. 2 is easily deduced from Scheme 3 and Eq. 1:

$$
\text { rate }=\frac{\mathrm{d} x}{\mathrm{~d} t}=k_{\mathrm{alk}} \frac{\left[\mathrm{H}^{+}\right]}{K_{a}+\left[\mathrm{H}^{+}\right]}[\mathrm{S}][\mathrm{NBP}] .
$$

We designate the fraction of sorbate converted into adduct by the alkylation reaction as $x$, let $\varepsilon_{\mathrm{NBP}}$ and $\varepsilon_{\mathrm{AD}}$ denote the molar absorption coefficients of NBP and $\mathrm{AD}$, respectively, and let $A_{\mathrm{o}}, A_{t}, A_{\infty}$ represent the initial absorbance, the absorbance at time $t$, and the final absorbance, respectively. Equations 3 to 5 can then be written as:

$$
\begin{aligned}
A_{\mathrm{o}} & =\varepsilon_{\mathrm{NBP}}[\mathrm{NBP}]_{\mathrm{o}}, \\
A_{t} & =\varepsilon_{\mathrm{NBP}}\left([\mathrm{NBP}]_{\mathrm{o}}-x\right)+x \varepsilon_{\mathrm{AD}},
\end{aligned}
$$


Table 1 Effect of $\mathrm{pH}$ on the NBP alkylation reaction for the sorbic acid $+\mathrm{KOH}$ and sorbic acid $+\mathrm{NaOH}$ systems in 7:3 (volume/volume) water + dioxane solvent mixtures. Conditions: $[\mathrm{NBP}]_{\mathrm{o}}=0.003 \mathrm{~mol} \cdot \mathrm{L}^{-1}$, $[\mathrm{KOH}]=[\mathrm{NaOH}]=0.1 \mathrm{~mol} \cdot \mathrm{L}^{-1}$, and $t=35.0^{\circ} \mathrm{C}$

\begin{tabular}{|c|c|c|c|c|c|}
\hline \multicolumn{3}{|c|}{$\mathrm{AH}+\mathrm{NBP}+\mathrm{KOH}$} & \multicolumn{3}{|c|}{$\mathrm{AH}+\mathrm{NBP}+\mathrm{NaOH}$} \\
\hline$\overline{\mathrm{pH}}$ & $\begin{array}{l}{[\mathrm{S}]} \\
\left(\mathrm{mol} \cdot \mathrm{L}^{-1}\right)\end{array}$ & $\begin{array}{l}k_{1} \times 10^{4 a} \\
\left(\min ^{-1}\right)\end{array}$ & $\overline{\mathrm{pH}}$ & $\begin{array}{l}{[\mathrm{S}]} \\
\left(\mathrm{mol} \cdot \mathrm{L}^{-1}\right)\end{array}$ & $\begin{array}{l}k_{1} \times 10^{4 a} \\
\left(\min ^{-1}\right)\end{array}$ \\
\hline- & - & - & 5.46 & 0.20 & $2.79 \pm 0.04$ \\
\hline 5.59 & 0.19 & $2.96 \pm 0.04$ & 5.59 & 0.19 & $2.32 \pm 0.03$ \\
\hline 5.65 & 0.18 & $2.35 \pm 0.02$ & 5.65 & 0.18 & $1.94 \pm 0.03$ \\
\hline 5.78 & 0.15 & $1.44 \pm 0.01$ & 5.80 & 0.15 & $1.26 \pm 0.01$ \\
\hline 5.89 & 0.14 & $1.07 \pm 0.02$ & - & - & - \\
\hline- & - & - & 6.05 & 0.13 & $0.53 \pm 0.02$ \\
\hline- & - & - & 6.32 & 0.11 & $0.37 \pm 0.01$ \\
\hline
\end{tabular}

${ }^{a}$ Values of the pseudo-first-order rate constant are given with their standard deviations

$$
A_{\infty}=\varepsilon_{\mathrm{AD}}[\mathrm{NBP}]_{\mathrm{o}} .
$$

Because the $\mathrm{pH}$ was kept constant (see Methods), and the experiments were performed with $[\mathrm{S}]$ in large excess, Eq. 2 can be rewritten in the form:

$$
\text { rate }=\frac{\mathrm{d} x}{\mathrm{~d} t}=k_{1}\left([\mathrm{NBP}]_{\mathrm{o}}-x\right)
$$

where $k_{1}$, the pseudo-first-order rate constant, is given by

$$
k_{1}=k_{\mathrm{alk}}\left[\mathrm{H}^{+}\right][\mathrm{S}] /\left(K_{a}+\left[\mathrm{H}^{+}\right]\right) .
$$

Integration of Eq. 6 and expressing the result in terms of the absorbance yields Eq. 8:

$$
k_{1} t=\ln \frac{A_{\infty}-A_{\mathrm{o}}}{A_{\infty}-A_{t}}
$$

where $A_{\infty}$ is the absorbance of the adduct when the plateau is reached (Fig. $2 a$ ). Figure $2 b$ shows the fit of the results to Eq. 8.

In order to check the possibility that a fraction of the NBP reagent was protonated, its $\mathrm{p} K_{a}$ in 7:3 (volume/volume) water + dioxane solvent mixtures was determined. Measurements carried out at $\lambda=261 \mathrm{~nm}$, where the maximum absorbance occurs, yielded $\mathrm{p} K_{a}=4.4$. Thus, significant protonation of NBP was ruled out.

Several experiments in the $\mathrm{pH}=5.0$ to 6.5 range were carried out for the $\mathrm{S}+\mathrm{KOH}$ and $\mathrm{S}+\mathrm{NaOH}$ systems. Table 1 shows the resulting variation in the pseudo-first-order rate constant values, $k_{1}$, with $\mathrm{pH}$.

To check the validity of Eq. 7, the $k_{1}$ values were plotted against those of $\left[\mathrm{H}^{+}\right][\mathrm{S}] /\left(K_{a}+\right.$ $\left.\left[\mathrm{H}^{+}\right]\right)$. Figure 3 shows the results, with $k_{\text {alk }}$ being the obtained slope of the line.

The values of $k_{\text {alk }}$ at different temperatures are shown in Table 2. Table 3 shows the activation parameters for $\mathrm{NBP}$ alkylation in the sorbate $+\mathrm{NaOH}$ and sorbate $+\mathrm{KOH}$ systems, as well as previous the results obtained in a hydrochloric acid medium [19]. Figure 4 depicts the good fit of the results by the Eyring equation [23]:

$$
k=\frac{k T}{h} e^{\Delta S^{\#} / R} e^{-\Delta H^{\#} / R T}=\frac{k T}{h} e^{-\Delta G^{\#} / R T} .
$$


Fig. 3 Variation of $k_{1}$ with $\left[\mathrm{H}^{+}\right][\mathrm{S}] /\left(K_{a}+\left[\mathrm{H}^{+}\right]\right)($Eq. 7$)$ in the $7: 3$ (volume/volume) water + dioxane solvent mixture for the $\mathrm{AH}+\mathrm{NBP}+\mathrm{NaOH}$ system. Conditions: [NaOH] $=0.1 \mathrm{~mol} \cdot \mathrm{L}^{-1}$, $[\mathrm{NBP}]_{\mathrm{o}}=0.003 \mathrm{~mol} \cdot \mathrm{L}^{-1}$, $K_{a}=1.8 \times 10^{-5}$, and $t=35.0^{\circ} \mathrm{C}$
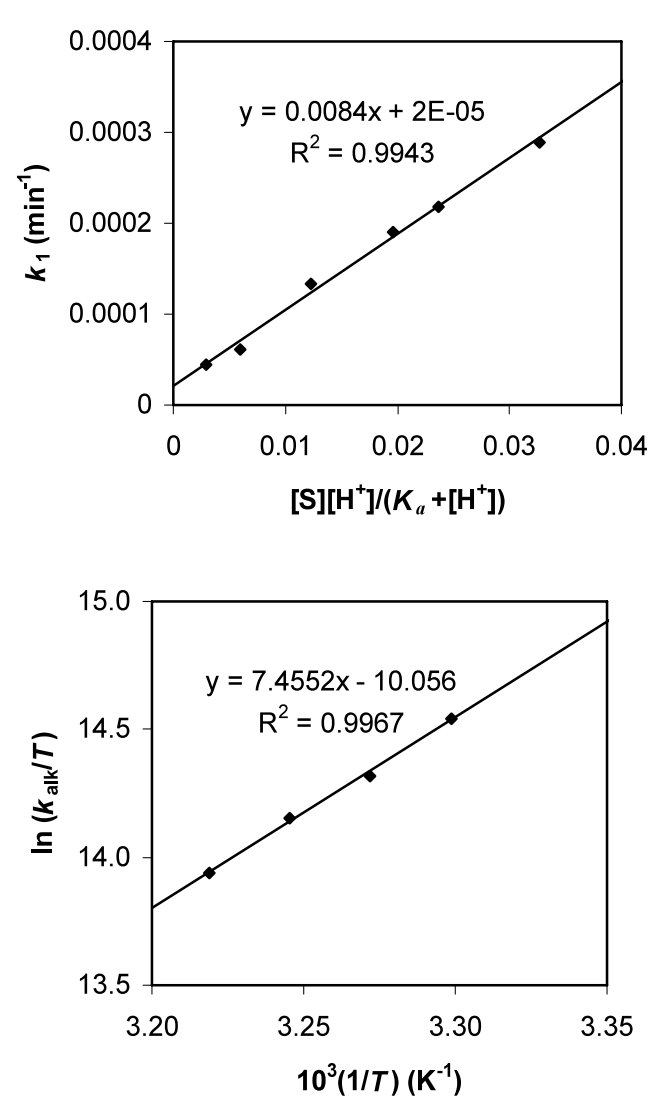

Fig. 4 Eyring plot for NBP alkylation by the sorbic acid + $\mathrm{KOH}$ system in 7:3

(volume/volume) water + dioxane solvent mixtures

Table 2 Rate constant as a function of temperature for NBP alkylation by the sorbic acid $+\mathrm{KOH}$ and sorbic acid $+\mathrm{NaOH}$ systems in 7:3 (volume/volume) water + dioxane solvent mixtures. Conditions: $[\mathrm{NBP}]_{\mathrm{o}}=$ $0.003 \mathrm{~mol} \cdot \mathrm{L}^{-1}$, and $[\mathrm{KOH}]=[\mathrm{NaOH}]=0.1 \mathrm{~mol} \cdot \mathrm{L}^{-1}$

\begin{tabular}{lll}
\hline$t\left({ }^{\circ} \mathrm{C}\right)$ & $k_{\mathrm{alk}} \times 10^{4 \mathrm{a}}\left(\mathrm{L} \cdot \mathrm{mol}^{-1} \cdot \mathrm{s}^{-1}\right)$ & \\
\cline { 2 - 3 } & $\mathrm{AH}+\mathrm{NBP}+\mathrm{KOH}$ & $\mathrm{AH}+\mathrm{NBP}+\mathrm{NaOH}$ \\
\hline 30.0 & $1.46 \pm 0.10$ & $1.30 \pm 0.04$ \\
32.5 & $1.85 \pm 0.06$ & $1.34 \pm 0.07$ \\
35.0 & $2.20 \pm 0.12$ & $1.40 \pm 0.05$ \\
37.5 & $2.75 \pm 0.07$ & $1.50 \pm 0.03$ \\
\hline
\end{tabular}

${ }^{a}$ Values of the rate constant are given with their standard deviations

The results obtained for the alkylation of NBP by sorbic acid $+\mathrm{NaOH}$ and sorbic acid + $\mathrm{KOH}$, as well as by potassium sorbate $+\mathrm{HCl}$, show that the activation parameters fluctuate over a wide range of values. The existence of a good $\Delta H^{\#} / \Delta S^{\#}$ isokinetic relationship (Fig. 5) supports the argument that all the reactions share a common mechanism [24]; this is logical because the active alkylating agent is always the same (sorbic acid) in the sorbic acid + sorbate mixtures studied here. Nevertheless, because the $\mathrm{K}^{+}$and $\mathrm{Na}^{+}$ions do not participate in any of the mechanism steps (Scheme 3 ), more experimental work is necessary 
Table 3 Activation parameters for NBP alkylation by sorbic acid + sorbate in the 7:3 (volume/volume) water + dioxane solvent mixtures

\begin{tabular}{lll}
\hline Alkylation mixture & $\Delta H^{\# \mathrm{a}}\left(\mathrm{kJ} \cdot \mathrm{mol}^{-1}\right)$ & $-\Delta S^{\# \mathrm{a}}\left(\mathrm{J} \cdot \mathrm{K}^{-1} \cdot \mathrm{mol}^{-1}\right)$ \\
\hline $\mathrm{AH}+\mathrm{NBP}+\mathrm{KOH}^{\mathrm{b}}$ & $62 \pm 3$ & $114 \pm 11$ \\
$\mathrm{AH}+\mathrm{NBP}+\mathrm{NaOH}^{\mathrm{b}}$ & $12 \pm 2$ & $279 \pm 20$ \\
$\mathrm{~K}^{+} \mathrm{A}^{-}+\mathrm{NBP}+\mathrm{HCl}^{\mathrm{c}}$ & $78 \pm 7$ & $70 \pm 12$ \\
\hline
\end{tabular}

${ }^{\text {a }}$ Values are given with their standard deviations

$\mathrm{b}_{\text {This work }}$

${ }^{\mathrm{c}}$ Values taken from Ref. [19]

Fig. 5 Isokinetic relationship for NBP alkylation by the sorbic acid + sorbate system in the $7: 3$ (volume/volume) water + dioxane solvent mixtures

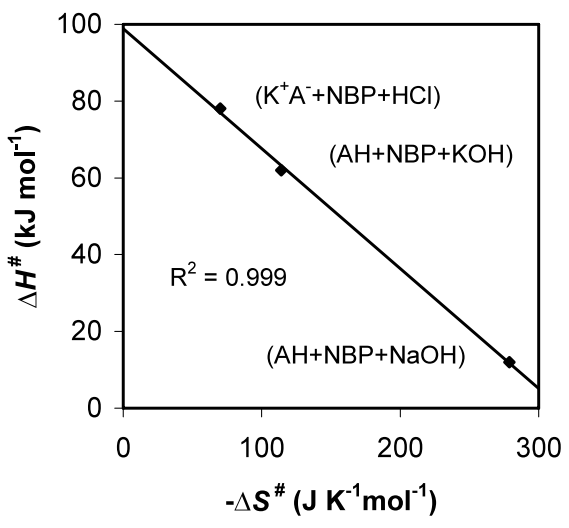

to rationalize the large differences observed for the $\Delta H^{\#} / \Delta S^{\#}$ values (Table 3). Possible causes of this difference could be either different values for the $K_{a}$ constant for the $\mathrm{AH}+$ $\mathrm{NaOH}$ and $\mathrm{AH}+\mathrm{KOH}$ systems or a strong salt-specific (cation) effect.

\section{Conclusions}

First, sorbic acid + sorbate mixtures show alkylating activity on the nucleophile 4-( $p$-nitro benzyl)pyridine (NBP), which is used as a trap for alkylating agents with nucleophilic characteristics similar to DNA bases. Second, the maximum alkylating capacity is observed in the $\mathrm{pH}=5.0$ to 6.5 range. Third, the alkylation reactions comply with the rate equation $r=k_{\mathrm{alk}}\left[\mathrm{H}^{+}\right][\mathrm{S}][\mathrm{NBP}] /\left(K_{a}+\left[\mathrm{H}^{+}\right]\right)$, with $K_{a}$ being the sorbic acid dissociation constant. Fourth, a $\Delta H^{\#} / \Delta S^{\#}$ compensation effect is observed by comparing the NBP alkylation reactions due to sorbic acid $+\mathrm{NaOH}$ and sorbic acid $+\mathrm{KOH}$, as well as for the potassium sorbate $+\mathrm{HCl}$ systems. Fifth, the results may help to establish suitable expiration times for products preserved with sorbic acid.

Acknowledgements The authors thank the Spanish Ministerio de Educación y Ciencia (Project CTQ200405048/BQU), as well as the Spanish Junta de Castilla y León (Grant SA011A05) for supporting the research reported in this article. M.T.P.P. and J.A.M. also thank the Ministerio de Educación y Ciencia and the Junta de Castilla y León for $\mathrm{PhD}$ grants. Thanks are also given for valuable comments made by the referees. 


\section{References}

1. Thakur, B.R., Singh, K., Arya, S.S.: Chemistry of sorbates-a basic perspective. Food Rev. Int. 10, 71-91 (1994)

2. Dacosta, Y.: L'acide sorbique et les sorbates. In: CDIUPA, Massy (1994)

3. U.S. Food and Drug Administration, Center for Food Safety and Applied Nutrition: FDA List of Food Additives that are Generally Recognized as Safe (GRAS). Rockville, MD (2005)

4. Ferrand, C., Marc, F., Fritsch, P., Cassand, P., de Saint Blanquat, G.: Genotoxicity study of reaction products of sorbic acid. J. Agric. Food Chem. 48, 3605-3610 (2000)

5. Münzer, R., Guigas, C., Renner, H.W.: Reexamination of potassium sorbate and sodium sorbate for possible genotoxic potential. Food Chem. Toxicol. 28, 397-401 (1990)

6. Schlater, J., Würgler, F.E., Kränzlin, R., Maier, P., Hollinger, E., Graf, U.: The potential genotoxicity of sorbates: effects on cell cycle in vitro in V79 cells and somatic mutations in Drosophila. Food Chem. Toxicol. 30, 843-851 (1992)

7. Würgler, F.E., Schlatter, J., Maier, P.: The genotoxicity status of sorbic acid, potassium sorbate and sodium sorbate. Mutat. Res. 283, 107-111 (1992)

8. Wedzicha, B.L., Brook, M.A.: Reaction of sorbic acid with nucleophiles: preliminary studies. Food Chem. 31, 29-40 (1989)

9. Khandelwal, G.D., Wedzicha, B.L.: Nucleophilic reactions of sorbic acid. Food Addit. Contam. 7, 685694 (1990)

10. Verbiscar, A.J., Campbell, K.N.: Unsaturated six-membered ring lactams. J. Org. Chem. 29, 2472-2474 (1974)

11. Khandelwal, G.D., Wedzicha, B.L.: Derivatives of sorbic acid-thiol reaction products. Food Chem. 37, 159-169 (1990)

12. Kito, Y., Namiki, M., Tsuji, K.: A new N-nitropyrrole. 1,4-dinitro-2-methylpyrrole formed by the reaction of sorbic acid with sodium nitrite. Tetrahedron 34, 505-508 (1970)

13. Kim, J.H., Thomas, J.J.: Use of 4-(4-nitrobenzyl)pyridine (4-NBP) to test mutagenic potential of slowreacting epoxides, their corresponding olefins, and other alkylating agents. Bull. Environ. Contam. Toxicol. 49, 879-885 (1992)

14. Shephard, S.E., Lutz, W.K.: Nitrosation of dietary precursors. Cancer Surv. 8, 401-421 (1989)

15. García Santos, M.P., Calle, E., Casado, J.: Amino acid nitrosation products as alkylating agents. J. Am. Chem. Soc. 123, 7506-7510 (2001)

16. García Santos, M.P., González Mancebo, S., Hernández Benito, J., Calle, E., Casado, J.: Reactivity of amino acids in nitrosation reactions and its relation to the alkylating potential of their products. J. Am. Chem. Soc. 124, 2177-2182 (2002)

17. Pérez Prior, M.T., Manso, J.A., García Santos, M.P., Calle, E., Casado, J.: Reactivity of lactones and GHB formation. J. Org. Chem. 70, 420-426 (2005)

18. Manso, J.A., Pérez Prior, M.T., García Santos, M.P., Calle, E., Casado, J.: A kinetic approach to the alkylating potential of carcinogenic lactones. Chem. Res. Toxicol. 18, 1161-1166 (2005)

19. Pérez Prior, M.T., Manso, J.A., García Santos, M.P., Calle, E., Casado, J.: Alkylating potential of potassium sorbate. J. Agric. Food Chem. 53, 10244-10247 (2005)

20. Tindall, G.W.: Mobile-phase buffers, part I: the interpretation of $\mathrm{pH}$ in partially aqueous mobile phases. LCGC North Am. 20, 1028-1032 (2002)

21. Eklund, T.: The antimicrobial effect of dissociated and undissociated sorbic acid at different $\mathrm{pH}$ levels. J. Appl. Bacteriol. 54, 383-389 (1983)

22. Food Safety \& Hygiene, Bulletin for the Australian Food Industry, p. 2 (June 2003)

23. Connors, K.A.: Chemical Kinetics The Study of Reaction Rates in Solution. VCH, New York (1990), pp. 208 and 246

24. Exner, O.: Correlation Analysis of Chemical Data. Plenum, New York (1988), Chap. 3 